\title{
Electrocardiographic abnormalities during exercise 3 weeks to 18 months after anterior myocardial infarction
}

\author{
J.-H. Atterhög, L.-G. Ekelund, and L. Kaijser \\ From the Department of Clinical Physiology, Karolinska Sjukhuset, Stockholm, Sweden
}

The electrocardiographic abnormalities produced by exercise at varying time intervals after an anterior myocardial infarction were studied in 12 patients. Three weeks after the infarction, exercise induced an obvious rise in the ST segment in leads over the infarcted area in Io patients. In the course of the ensuing months this reaction to exercise gradually disappeared, and in some subjects exercise then produced ST segment depression. The ST rise produced by exercise in the early phase after an infarction is interpreted as a sign of anoxia in the infarcted zone, and the rate at which this pattern resolves may be of prognostic value. These changes in the $S T-T$ wave produced by exercise were not found in left praecordial leads distant from the site of infarction. The $T$ wave amplitude was found to be increased during exercise at all times after infarction, but this change is nonspecific.

The effect of exercise on the electrocardiogram is used extensively as a method of diagnosis of the presence of ischaemic heart disease. However, little attention has been paid to the effects of exercise on the electrocardiogram during the period after acute infarction. The purpose of the present study was therefore to examine the electrocardiographic pattern and sequential effects of exercise during the time course in a group of patients at intervals from 3 weeks to 18 months after the onset of acute myocardial infarction. Furthermore, it was considered to be of interest to see if the changes might be of prognostic value.

\section{Patients}

Since 1968 an exercise test performed 3 weeks after the onset of symptoms of acute myocardial infarction has been a routine part of the management of all patients admitted to Karolinska Sjukhuset with this diagnosis, unless cardiac failure, arrhythmias, or other contraindications are present at this time. Tests were repeated at varying intervals up to 18 months in 150 patients who were willing to attend the hospital for this purpose. All patients with anterior myocardial infarction who had never received digitalis and who had had two or more tests performed during the period were examined. Patients with anterior infarction were chosen because this area is well represented in the conventional leads during exercise (Scandinavian Committee on ECG

Received I4 January 1971.
Classification, 1967). Twelve patients with a mean age of 58 years fulfilled these criteria. They had all given a typical history of acute myocardial infarction. Ten patients had had abnormal $Q$ waves ( $>0.04 \mathrm{sec}$ ) accompanied by ST-T wave rise in leads $\mathrm{CR2}_{2} 4$ and raised levels of serum enzymes (CPK, GOT, or LDH). Two patients had had ST-T wave rises and raised levels of serum enzymes without the development of abnormal $Q$ waves. The clinical data are summarized in the Table.

\section{Methods}

In addition to the test at 3 weeks, 9 of the 12 had tests between 2 and 4 months, 9 between 5 and 6 months, and 6 a year or more after infarction. Exercise was performed in the sitting position on an electrodynamically braked cycle ergometer (Holmgren and Mattsson, 1954) with stepwise increasing loads (Sjöstrand, 1947; Wahlund, 1948). The first load was $100-300 \mathrm{kpm} / \mathrm{min}$, depending on the amount of work the patient was expected to tolerate, and the load was increased by $100-300 \mathrm{kpm} / \mathrm{min}$ every sixth minute. On the first occasion after the infarction, the exercise was continued until the heart rate had reached 120 to 130 beats a minute. In no subject was permanent damage to the myocardium induced by the work test, as evidenced by electrocardiograms over the next few days. In later exercise tests the heart rate was allowed to increase to about 150 beats a minute unless frequent ectopic beats or angina occurred.

The electrocardiogram was recorded with an ink-jet electrocardiograph (Elema, Mingograf 8I) 
TABLE Clinical data of 12 patients with anterior myocardial infarction examined repeatedly with exercise electrocardiogram

\begin{tabular}{|c|c|c|c|c|c|c|c|}
\hline $\begin{array}{l}\text { Case } \\
\text { No. }\end{array}$ & Sex & $\begin{array}{l}\text { Age } \\
(y r)\end{array}$ & $\begin{array}{l}\text { Duration of } \\
\text { coronary disease } \\
\text { previous to infarction }\end{array}$ & Other diseases & $\begin{array}{l}\text { Type of } \\
Q R S \\
\text { complex }\end{array}$ & $\begin{array}{l}\text { Max. GOT } \\
\text { values } \\
\text { (units) }\end{array}$ & Complications \\
\hline I & $\mathbf{M}$ & 62 & - & - & $Q>0.04 \mathrm{sec}$ & $<$ IOO & - \\
\hline 2 & $\mathbf{M}$ & 54 & $\begin{array}{l}\text { Angina pectoris } \\
5 \mathrm{yr}\end{array}$ & $\begin{array}{l}\text { Moderate hyper- } \\
\text { tension } 5 \mathrm{yr}\end{array}$ & , & $100-200$ & 一 \\
\hline 3 & $\mathbf{M}$ & 6I & $\begin{array}{l}\text { Slight angina } \\
\text { pectoris } 2 \text { wk }\end{array}$ & 一 & ” & $>200$ & - \\
\hline 4 & $\mathbf{M}$ & 66 & $\begin{array}{l}\text { Lateral infarc- } \\
\text { tion } 3 \mathrm{wk} \\
\text { earlier }\end{array}$ & 一 & ” & $100-200$ & $\begin{array}{l}\text { Atrial fibrillation on admission, fre- } \\
\text { quent ventricular ectopic beats } \\
\text { first days in hospital }\end{array}$ \\
\hline $\begin{array}{l}5 \\
6\end{array}$ & $\begin{array}{l}\text { M } \\
\text { F }\end{array}$ & $\begin{array}{l}58 \\
46\end{array}$ & $-\quad »$ & $\begin{array}{l}\text { Gout ? } \\
\text { Moderate hyper- } \\
\text { cholesterolaemia }\end{array}$ & No Q" wave & $\begin{aligned}> & 200 \\
& 100-200\end{aligned}$ & $\overline{-}$ \\
\hline 7 & $\mathbf{M}$ & $6 I$ & $\begin{array}{l}\text { Angina pectoris } \\
\text { I } \mathrm{mth}\end{array}$ & - & " & $<100$ & $\begin{array}{l}\text { Heart rate }<50 \text { beats/min on } \\
\text { admission, frequent ventricular } \\
\text { ectopic beats first days in hospital }\end{array}$ \\
\hline 8 & $\mathbf{M}$ & 57 & 一 & - & $Q>0.04 \mathrm{sec}$ & $<100$ & - \\
\hline 9 & $\mathbf{M}$ & 49 & 一 & $\begin{array}{l}\text { Abnormal glucose } \\
\text { tolerance test }\end{array}$ & , & $100-200$ & - \\
\hline I0 & $\mathbf{F}$ & 69 & $\begin{array}{l}\text { Angina pectoris } \\
3 \mathrm{dy}\end{array}$ & $\begin{array}{l}\text { Moderate } \\
\text { hypertension }\end{array}$ & " & $>200$ & - \\
\hline I I & $\mathbf{M}$ & 54 & $\begin{array}{l}\text { Angina pectoris } \\
4 \mathrm{yr}\end{array}$ & $\begin{array}{l}\text { Abnormal glucose } \\
\text { tolerance test }\end{array}$ & " & $<100$ & - \\
\hline I2 & $\mathbf{M}$ & 58 & - & $\begin{array}{l}\text { Hypoplastic } \\
\text { anaemia of } \\
\text { moderate degree }\end{array}$ & " & $100-200$ & - \\
\hline
\end{tabular}

*Normal value $<25$ units.

at a paper speed of $50 \mathrm{~mm} / \mathrm{sec}$ and a calibration of $\mathrm{I} \mathrm{mV}$ equal to Io $\mathrm{mm}$ amplitude. Six chesthead leads ( $\mathrm{CH}$ leads) were used (Sjöstrand, I95I ; Holmgren and Strandell, I96r). The abnormalities were examined in the lead showing the deepest $Q$ wave corresponding approximately to the centre of the infarction (lead $\mathrm{CH}_{2}$ in 7 subjects, $\mathrm{CH}_{4}$ in 5 subjects) and also in $\mathrm{CH}_{7}$, representing the non-infarcted lateral part of the left ventricle. Alterations of the ST segment from the isoelectric line were measured $20 \mathrm{msec}$ after the S-ST segment junction. The $T$ wave was measured at its highest positive value and, when diphasic or negative, also at its most negative point. The average of 3 consecutive heart cycles was used.

\section{Results}

Work performance In the first exercise test, when the work load was limited to give a heart rate of $120-130$ beats/min the average final load was $370 \mathrm{kpm} / \mathrm{min}$ (range I ro-600), with an average final heart rate of 124 beats/ min (range 95-I 42, the highest rate depending on an obvious increase of the heart rate between two loads). Between 5 and 6 months after the infarction the average final load was 600 $\mathrm{kpm} / \mathrm{min}$ (range 400-800) and the average final heart rate 130 beats/min (range I I 5-I44). Those patients examined 5 to 6 months after the infarction had increased their working capacity at a heart rate of $I 30\left(W_{130}\right)$ from 400 $\mathrm{kpm} / \mathrm{min}$ (range 50-625) at 3 weeks to 590 $\mathrm{kpm} / \mathrm{min}$ (range 475-925).

Angina pectoris of the I2 patients, 3 stopped exercising because of angina pectoris at the 3-week and subsequent tests. The remaining 9 were able to reach the heart rate limit at the 3-week test, but 2 of these devel-

FIG. I Relation between heart rate (beats/ min) and the ST level in the I2 subjects during exercise 3 weeks after acute myocardial infarction. ST level measured in a lead corresponding to the centre of the infarcted area. Numbers refer to the case numbers of the patients.

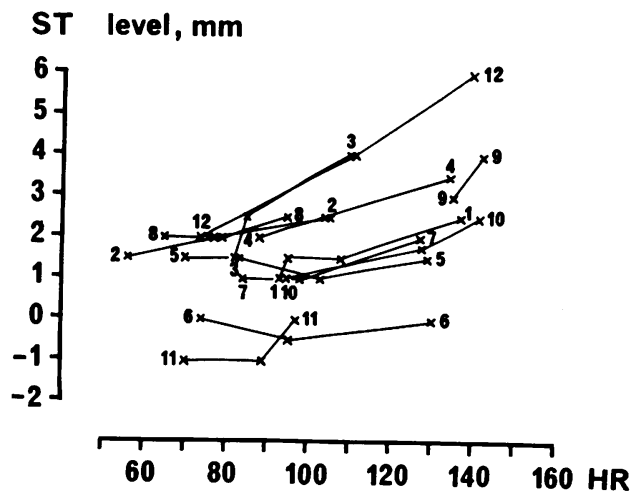


FIG. 2 Relation between heart rate during exercise and $T$ wave amplitude (measured in the same lead as in Fig. I). Patients with diphasic $T$ waves are represented by two lines indicating the most positive and the most negative part of the $T$ wave ( $x=$ positive, $o=$ negative).

oped angina during a later test when achieving higher heart rates.

Electrocardiographic abnormalities 3 weeks after infarction The ST segment in the anterior wall leads $\left(\mathrm{CH}_{2}-4\right)$ had an average level of $+1 \cdot 3 \mathrm{~mm}$ (range -1 to +3 $\mathrm{mm}$ ). During exercise there was a continuous increase in the ST segment rise with rising heart rate in ro subjects (average $+\mathrm{I} \cdot 6$ $\mathrm{mm}$, range +0.5 to $+4 \mathrm{~mm}$ ) (Fig. $\mathrm{I}$ ). Of the remaining 2 subjects, one had isoelectric $S T$ segment at rest and no $Q$ wave. The $T$ wave amplitude increased in all subjects. In those subjects with a negative $T$ wave component, this decreased and in most cases became positive (Fig. 2). At higher heart rates the ST-T wave configuration resembled that during an acute infarction in all but 2 patients. There were no differences between patients with and without chest pain during exercise. No changes in the QRS configuration occurred during the test. Two examples of the electrocardiographic abnormalities are shown in Fig. 3 and 4.

In lead $\mathrm{CH}_{7}, 9$ subjects showed slight ST segment depression of the type considered to be normal in relation to the increased heart rate (Sjöstrand, 1950). Three subjects developed pronounced ST-T changes considered typical of coronary insufficiency as described by, among others, Kaijser (1966) and Areskog et al. (1967) (Fig. 5). Angina pectoris developed in one patient with abnormal ST-T changes in $\mathrm{CH}_{7}$ and in 2 of the patients without such changes.

Electrocardiographic abnormalities 2 to 4 months after infarction At rest, 2 of the 9 patients tested had an ST level of $O$ to $+0.5 \mathrm{~mm}$, and 7 had an ST level of $+\mathrm{I}$ to $+\mathrm{r} .5 \mathrm{~mm}$ in leads $\mathrm{CH}_{2}-4$. During exercise 2 patients had a considerable further increase in ST level with increasing heart rate $(+3$ to

FIG. 3 Case 12, transmural infarction. Leads: $\mathrm{CH}_{4} \mathrm{R}-\mathrm{CH}_{7}$ resting electrocardiogram on the left. Upper part: on exercise 3 weeks after infarction. Lower part: on exercise 6 weeks after infarction.
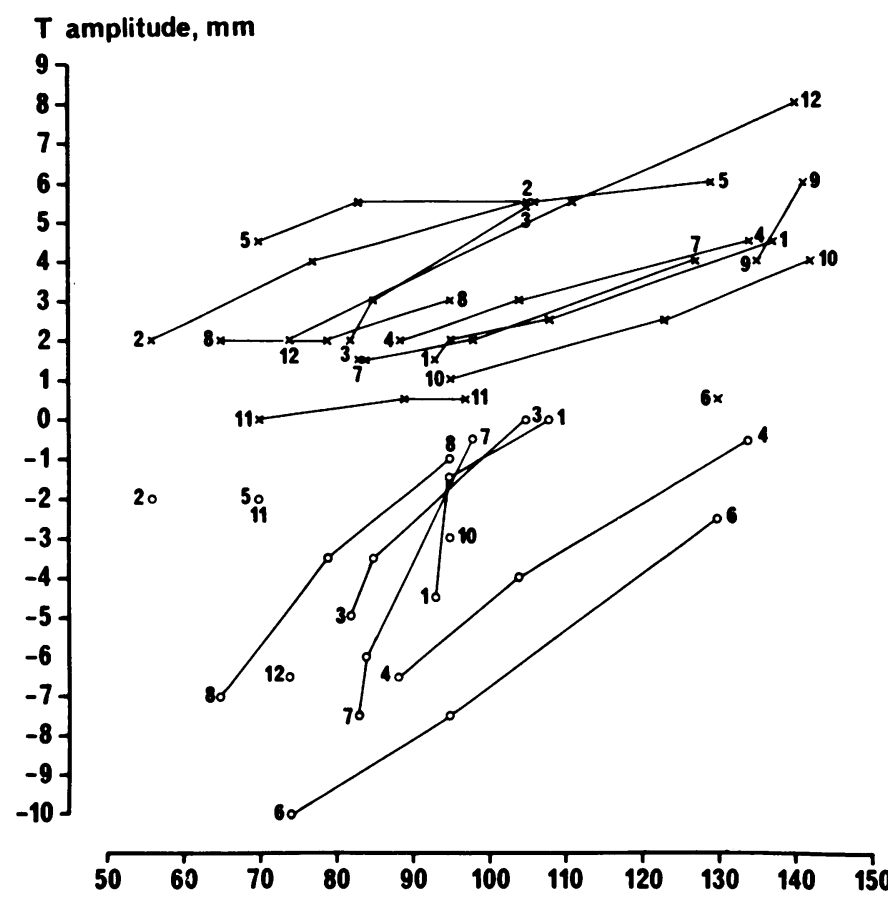

HR
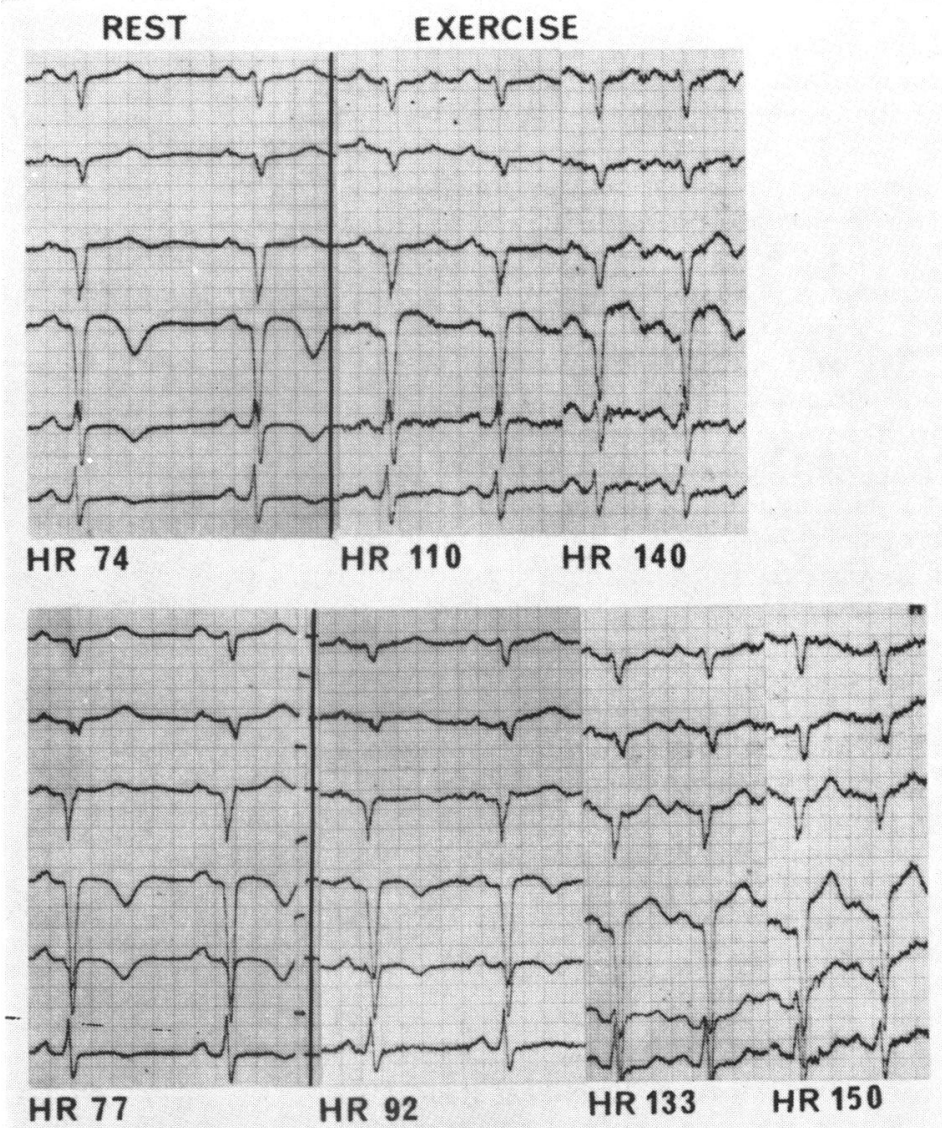
FIG. 4 Case 7, subendocardial infarction. Leads: $\mathrm{CH}_{4} \mathrm{R}-\mathrm{CH} 7$ resting electrocardiogram on the left. Upper part: on exercise 3 weeks after infarction. Lower part: on exercise 9 weeks after infarction.

$+4 \mathrm{~mm}), 3$ had a slight increase $(+0.5$ to $+1.5 \mathrm{~mm}$ ), and in 2 the ST segment remained at the same level. Two patients had a I to $1.5 \mathrm{~mm}$ depression of the ST level. Two examples of the electrocardiographic abnormalities are shown in Fig. 3 and 4.

Electrocardiographic abnormalities 5 to 6 months after infarction At rest, 4 of the 9 patients tested had an ST segment level of 0 to $+\mathrm{I} \mathrm{mm}$, and 5 had an ST segment level of $+\mathrm{I} \cdot 5$ to $+2 \mathrm{~mm}$ in leads $\mathrm{CH}_{2}-4$. During exercise, 3 patients had a further ST segment increase of +0.5 to $+3 \mathrm{~mm}$; in 2 the ST segment remained unchanged; and in 4 subjects there was a depression of 0.5 to 2 mm (Fig. 6). The $T$ wave amplitude at rest became more positive compared to the 3-week test, and increased during exercise as it had done during the 2 to 4 month test (Fig. 7).

Electrocardiographic abnormalities 12 to 18 months after infarction At rest, 3 of the 6 patients studied had an ST segment level of +0.5 to $+\mathrm{I} \mathrm{mm}$ and 3 an ST segment level of $+\mathrm{I} .5 \mathrm{~mm}$ in leads $\mathrm{CH}_{2}-4$. During exercise 3 patients showed an increase of the ST level ( $+\mathrm{I}$ to $+2.5 \mathrm{~mm}$ ) and 3 a depression of the ST segment (I to $2 \mathrm{~mm}$ ).

Time course of ST-T wave changes The time course of the change in ST segment response to exercise is summarized in Fig. 8. The greatest decrease in the exercise-induced ST rise appears to occur during the first 2 months. In no patient in whom an exercise test was performed in the second month or later after the infarction was there ST-T segment deviation of the configuration seen in an acute infarction.

The $T$ wave amplitude during exercise at the same heart rate but at different times after the infarction is summarized in Fig. 9. The amplitude became more positive during the first 3 months and then appeared to remain at this level.

During the early months, the QRS con-

FIG. 5 Relation between heart rate and $S T$ and $\mathrm{T}$ level in lead $\mathrm{CH}_{7}$ during exercise 3 weeks after infarction. Recordings made simultaneously with those presented in Fig. I.
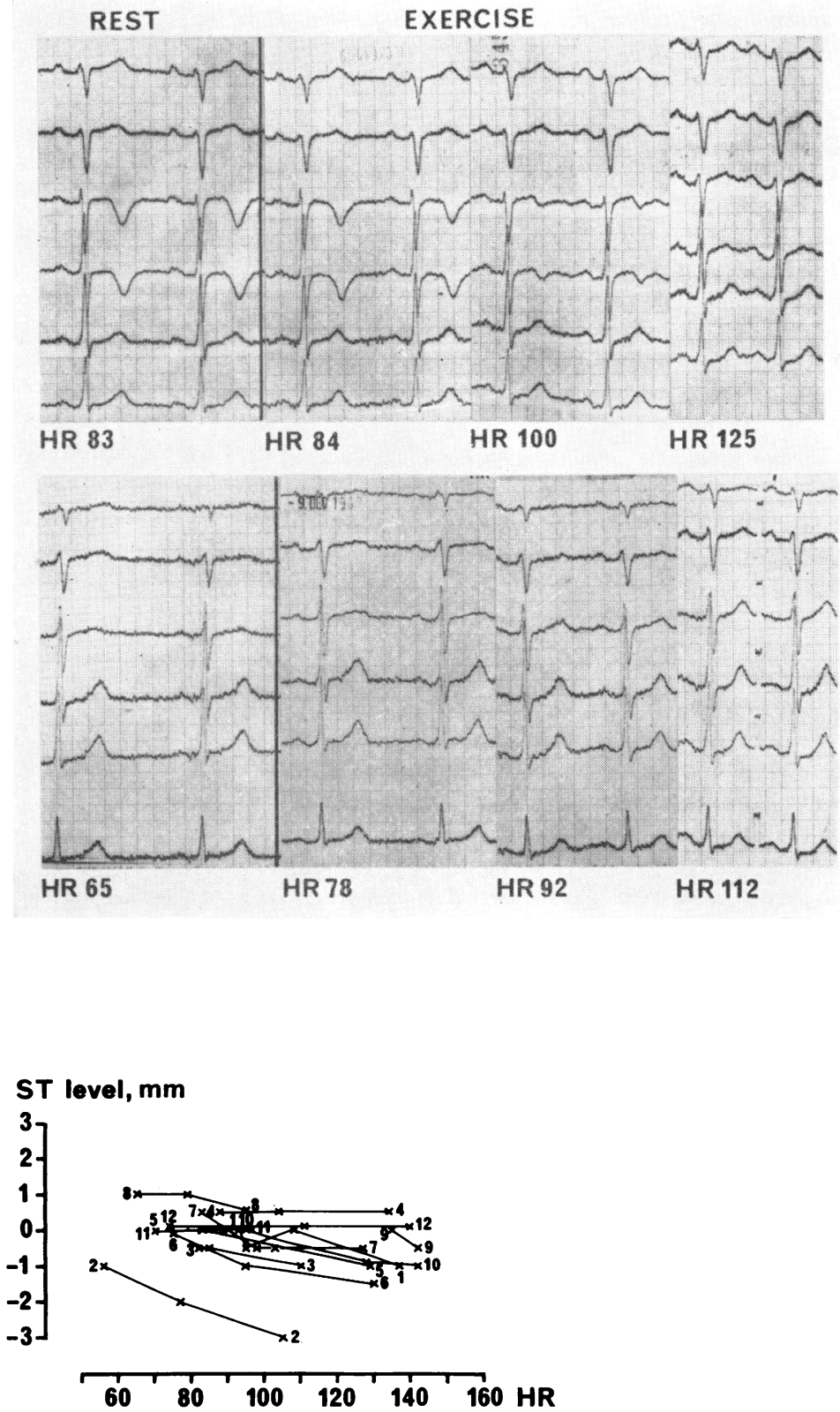

T amplitude, $\mathrm{mm}$

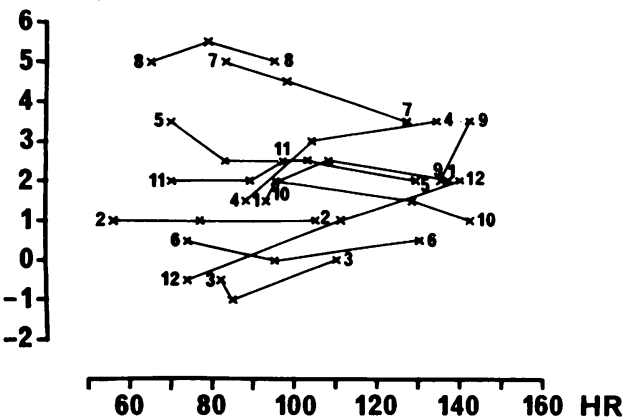




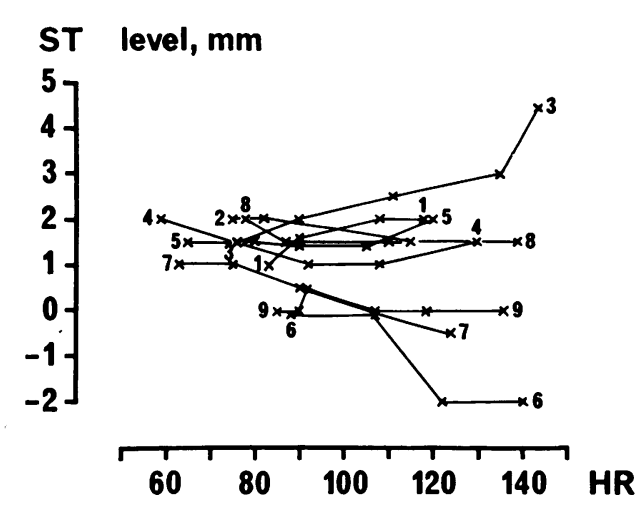

FIG. 6 Relation between heart rate and ST level during exercise 5 to 6 months after the infarction. ST level measured in a lead corresponding to the centre of the infarction.

figuration changed in 3 patients with an appearance of a small $R$ wave.

\section{Discussion}

ST segment Reversible ST increases resembling those recorded in an acute infarction have been described earlier in connexion with attacks of angina pectoris (Wilson and Johnston, I94I; Randles and Fradkin, 1948; Myers and Talmers, 1955; Prinzmetal et al., 1959). Bellet et al. (1962) found that in some patients with angina pectoris ST rise could be induced by exercise. In postinfarction patients, Söderholm et al. (I962) occasionally found ST rise during exercise. Ekelund and Strandell (1960) called attention to the occurrence of ST rise during exercise when studying the electrocardiographic reaction 6 months after infarction. However, the electrocardiographic reaction during exercise in the first few weeks after an infarction and the time course of the change in exercise electrocardiographic pattern in the postinfarction period have not been described previously.

The underlying cause of the ST rise seen in the early weeks after an acute infarction is not known. The probable explanation is that the partially ischaemic zone round the infarction becomes anoxic during exercise and, in consequence, ST rise develops, similar to that seen in an acute infarction. In later tests exercise no longer produces the appearance of an acute infarction. During this period the hypoxic cells have either recovered due to improved collateral blood flow or have been replaced by fibrous tissue. Thus a complete demarcation between impaired and nor-

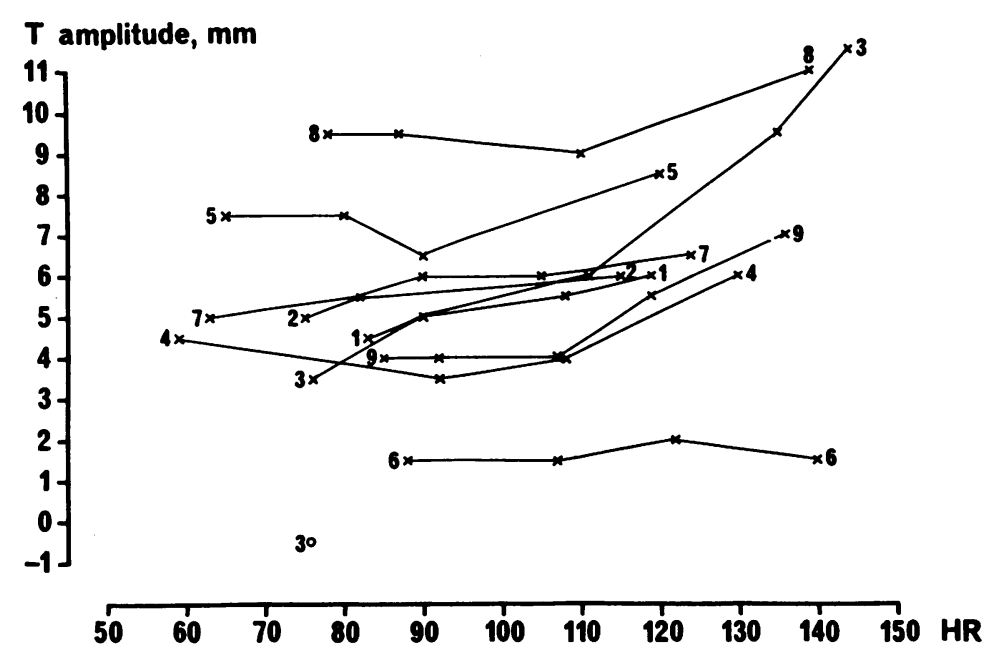

FIG. 7 Relation between heart rate and $T$ wave amplitude during exercise 5 to 6 months after the infarction (measured in the same lead as in Fig. 6).

FIG. 8 Change in ST level with exercise at different times after myocardial infarction (measured in a lead corresponding to the centre of the infarction). ST level measured in each individual at the same heart rate ( \pm 5 beats) in each exercise test. Mean heart rate 117 beats/min (range 90-140). (One patient is excluded because of obvious variation in heart rate during different exercise tests.)

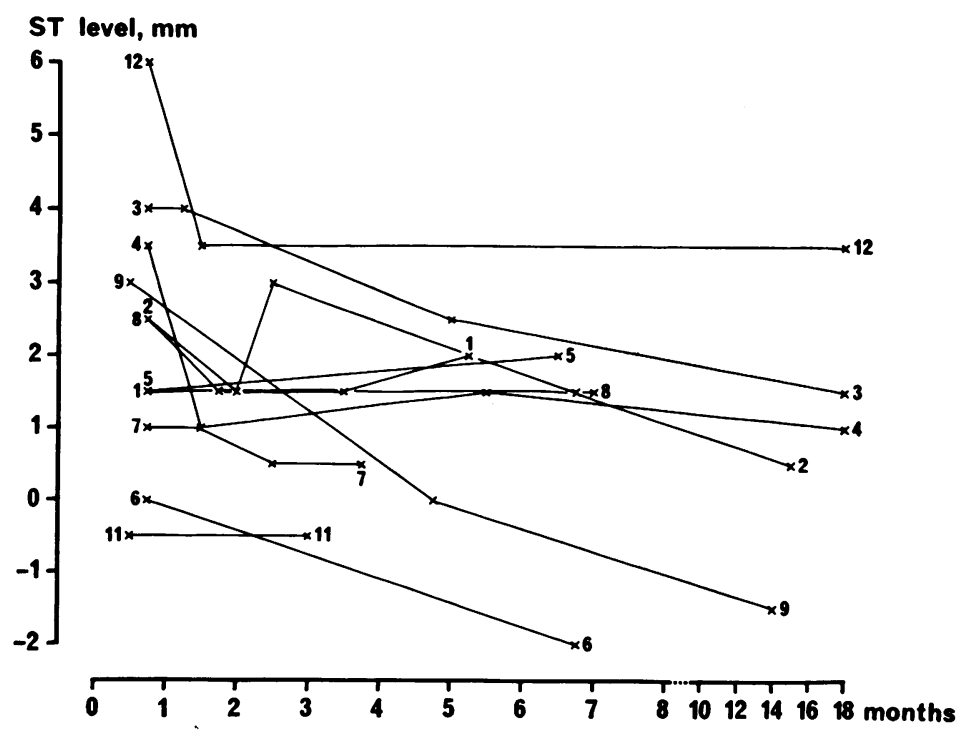


mal tissue has developed and then the pathophysiological basis for the conspicuous ST rise produced by exercise no longer exists. Formation of granulation tissue is normally complete throughout the infarcted area 3 to 4 weeks after the signs of infarction and changes to a less cellular and less vascular granulation tissue during the next 2 to 3 months. After about 3 months a fully fibrous scar has developed (Mallory, White, and Salcedo-Salgar, 1939). Thus the time course for the change in the electrocardiogram responses to exercise seems to parallel the morphological changes of healing. The changing pattern of the ST reaction during exercise may thus be of prognostic value as a possible indication of the condition of the injured myocardium.

T wave During the months after infarction the $T$ wave inversion in the resting electrocardiogram may partly or totally resolve (Bohning and Katz, I935; Langendorf and Pick, 1938). The increased positive amplitude of a negative or low $T$ wave over the infarcted area induced by exercise during the early weeks after an infarction and later is not specific but is seen after a large variety of injuries to the myocardium (Fritzlar, 1940; Klemola, I942; Bengtsson, 1957; Rihl, Huttmann, and Spiegl, 1935; Stokes, 1946; Lepeschkin, 195 I ; Thorén, 1964).

$\mathrm{CH}_{7}$ The electrocardiographic changes seen in the lateral lead $\mathrm{CH}_{7}$ during exercise 3 weeks after the infarction (Fig. 5) indicate that an electrocardiogram in the neighbourhood of the infarction is not necessarily disturbed by the changes occurring in the infarcted area. The ST-T wave changes during exercise may be normal or show the pattern typical of coronary insufficiency depending on the blood supply in that region in relation to the work load. The changes in $\mathrm{CH}_{7}$ cannot just be reflecting what is occurring in the infarcted area as they remain in later exercise tests when the anterior electrocardiographic abnormalities have another pattern. Consequently, a correct electrocardiographic diagnosis of coronary insufficiency from the exercise test may still be obtainable.

\section{References}

Areskog, N.-H., Björk, L., Björk, V. O., Hallén, A., and Ström, G. (1967). Physical work capacity, Ecg reaction to work test and coronary angiogram in coronary artery disease. Acta Medica Scandinavica, Suppl. 472, p. 9.

Bellet, S., Eliakim, M., Deliyiannis, S., and LaVan, D. (1962). Radioelectrocardiography during exercise in patients with angina pectoris. Circulation, 25, 5.

Bengtsson, E. (1957). Electrocardiographic studies in patients with abnormalities in serial examinations
T amplitude, $\mathbf{m m}$

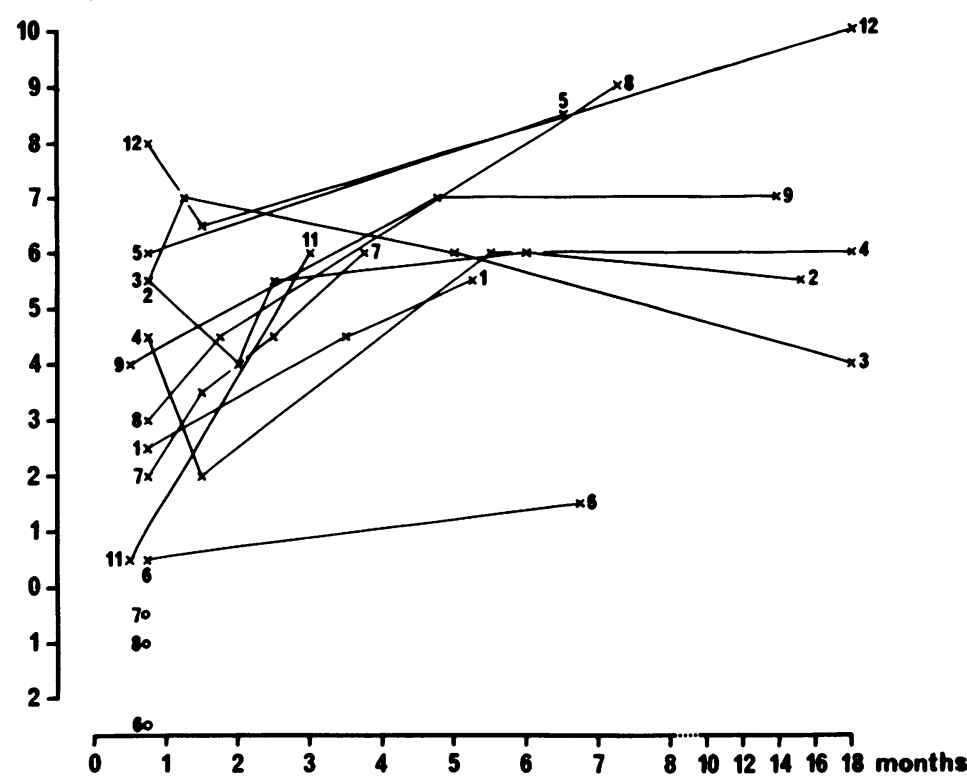

FIG. 9 Change in $T$ wave amplitude with exercise at different times after myocardial infarction, from the same leads, loads, and exercise tests as in Fig. 8.

with standard leads during acute infectious diseases. II. Chest and extremity leads during and after exercise. Acta Medica Scandinavica, 159, $4 \mathrm{I}$ I.

Bohning, A., and Katz, L. N. (1935). The four-lead electrocardiogram in coronary sclerosis. A study of a series of consecutive patients. American fournal of the Medical Sciences, 189, 833.

Ekelund, L.-G., and Strandell, T. (1960). EKGreaktionen under och efter arbete hos män med tidigare genomgången hjärtinfarkt. Report given at the meeting of the Swedish Society for Clinical Physiology.

Fritzlar, G. (1940). Das Verhalten der Nachschwankung im Belastungselektrokardiogramm bei schweren Myokardschäden und Kammerextrasystolen. Zeitschrift für Kreislaufforschung, 32, 409.

Holmgren, A., and Mattsson, K. H. (1954). A new ergometer with constant work load at varying pedalling rate. Scandinavian fournal of Clinical and Laboratory Investigation, 6, 137.

Holmgren, A., and Strandell, T. (I96I). On the use of chest-head leads for recording of electrocardiogram during exercise. Acta Medica Scandinavica, 169, 57.

Kaijser, L. (1966). EKG-förändringar vid koronarinsufficiens som funktion av arbetsintensitet och duration. Läkartidningen, 63, 3340 .

Klemola, E. (1942). Untersuchungen über das Belastungselektrokardiogramm bei Myokardschädigungen nach akuten Infektionskrankheiten. Acto Societatis Medicorum Fennicae "Duodecim", 32, 59.

Langendorf, R., and Pick, A. (1938). Zur Diagnose des Myokardinfarktes mit Hilfe von Brustwandableitungen. Acta Medica Scandinavica, 96, 80.

Lepeschkin, E. (I95I). Modern Electrocardiography. Vol. I: The P-Q-R-S-T-U complex. Williams and Wilkins, Baltimore. 
Mallory, G. K., White, P. D., and Salcedo-Salgar, J. (1939). The speed of healing of myocardial infarction. A study of the pathologic anatomy in seventytwo cases. American Heart fournal, 18, 647.

Myers, G. B., and Talmers, F. N. (1955). The electrocardiographic diagnosis of acute myocardial ischemia. Annals of Internal Medicine, 43, 36I.

Prinzmetal, M., Kennamer, R., Merliss, R., Wade, T., and Bor, N. (1959). Angina pectoris. I. A variant form of angina pectoris. American fournal of Medicine, 27, 375.

Randles, F. S., and Fradkin, N. F. (1948). Electrocardiographic alterations resembling those produced by myocardial infarction observed during a spontaneous attack of angina pectoris. Annals of Internal Medicine, 28, 671.

Rihl, J., Huttmann, A., and Spiegl, E. (1935). Uber das Arbeitselektrokardiogramm. Zeitschrift für Kreislaufforschung, 27, 659.

Scandinavian Committee on ECG Classification (1967). The 'Minnesota Code' for ECG classification. Adaptation to CR leads and modification of the code for ECGs recorded during and after exercise. Acta Medica Scandinavica, Suppl. 48I.

Sjöstrand, T. (1947). Changes in the respiratory organs of workmen at an ore smelting works. Acta Medica Scandinavica, Suppl. 196, p. 687.
Sjöstrand, T. (1950). The relationship between the heart frequency and the S-T level of the electrocardiogram. Acta Medica Scandinavica, 138, 201.

Sjöstrand, T. (195I). The electrocardiographic work and hypoxemia tests. Scandinavian fournal of Clinical and Laboratory Investigation, 3, I.

Söderholm, B. Thulesius, O., Heyman, F., Malmcrona, R., and Björntorp, P. (1962). Myocardial infarction in the younger age groups. III. Followup observations with special reference to exercise tolerance tests. Acta Medica Scandinavica, 172, 585 .

Stokes, W. (1946). The effect of nitrite and exercise on the inverted T wave. British Heart fournal, 8, 62.

Thorén, C. (1964). Cardiomyopathy in Friedreich's ataxia. With studies of cardiovascular and respiratory function. Acta Paediatrica, 53, Suppl. I 53.

Wahlund, H. (1948). Determination of the physical working capacity. A physiological and clinical study with special reference to standardization of cardiopulmonary functional tests. Acta Medica Scandinavica, Suppl. 215.

Wilson, F. N., and Johnston, F. D. (I94I). The occurrence in angina pectoris of electrocardiographic changes similar in magnitude and in kind to those produced by myocardial infarction. American Heart fournal, 22, 64 . 